\title{
Well Log Analysis and Oil Potentialities of the Lower Cretaceous Nubia Sandstones, West Esh El Mallaha Oilfield, Southern Gulf of Suez, Egypt
}

\author{
Said A. Aly ${ }^{1 *}$, Hatem F. Ewida ${ }^{2}$, Ayman Shebl $^{1}$ and Ibrahem A. Nasr ${ }^{3}$ \\ ${ }^{l}$ Geophysics Department, Faculty of Science, Ain Shams University, Cairo, Egypt, \\ ${ }^{2}$ GUPCO - British petroleum (BP), \\ ${ }^{3}$ Ganoub El-Wadi petroleum holding company (Ganope)-[Deputed in Esh El Mallaha petroleum company], Cairo, Egypt
}

A R T I C L E I N F O

Article history:

Received 13 June 2015

Accepted 05 August 2015

Keywords:

Well Log Analysis;

Lower Cretaceous age;

Nubia Sandstones;

West Esh El Mallaha Oilfield;

Gulf of Suez.

\begin{abstract}
A B S T R A C T
Nubia A rock unit is one of the best reservoirs in the Gulf of Suez region and is dated as of Lower Cretaceous age. This study is concerned as the petrophysical evaluation and well $\log$ analysis of Nubia A for 4 wells at the West Esh El Mallaha Oilfield, Southern Gulf of Suez, Egypt. Computer-assisted log analyses were used to evaluate the petrophysical parameters such as shale volume, total and effective porosities, water, hydrocarbon and flushed zone saturations, reservoir and pay flags. Cross-plots of the petrophysical parameters versus depth were illustrated. The Nuabia A rock unit refers to the matrix components mainly sandstone with some kaolinaite and shale contents. In this study, the Nubia A rock unit differs slightly in thickness in the study area. The capacity of the Nubia A rock unit is assessed from the well-log analysis through the examination of the total and effective porosities. Nubia A rock unit is interpreted from 4 studied wells as a good quality reservoir rocks with high average effective porosity reaching up to $21 \%$ and high average hydrocarbon saturation reaching up to $68 \%$.
\end{abstract}

\section{Introduction}

The present work deals with the subsurface geologic setting and petrophysical characteristics of the Nubia A rock unit of West Esh El Mallaha oilfield (Fig. 1) for more exploration and development activities in the southern Gulf of Suez area. West Esh El Mallaha Oilfield lies on the onshore western side of the Gulf of Suez on its southern portion. The field is about $12.3 \mathrm{Km}$ east of the Hurghada shoreline. West Esh El Mallaha oilfield is producing from Pre-Miocene and Miocene reservoirs. The Nubia sandstones is expressed as the one of the main interested reservoirs in the West Esh El Mallaha oilfield.

\section{Geologic Setting}

The Gulf of Suez is one of the best examples of the integration of outcrop and subsurface data to enhance hydrocarbon exploration and exploitation ${ }^{[1-4]}$. In spite of abundant new stratigraphic and structural data for parts of the basin, no comprehensive analysis and integration of all areas of the rift has been published (e.g., ${ }^{[2,5,6]}$ ). Specifically, the major differences in the tectonostratigraphic histories of the southern and central rift basins have never been adequately addressed ${ }^{[7]}$.

\footnotetext{
* Corresponding author.

E-mail address: aessaiy@sci.asu.edu.eg
}

The Suez rift is characterized by a zigzag fault pattern, composed of N-S to NNE-SSW, E-W and NW-SE striking extensional fault systems both at the rift borders and within the rift basins ${ }^{[2,5,6,8,9]}$ (Figs. 2 and 3).

The structure frame work on the West Esh El Mallaha Oilfield is controlled by the general structure trend of the southern Gulf of Suez portion, NW-SE as Clysmic fault trend and NE-SW as Cross element fault trend. The structure cross section C-C' (Fig. 2) shows the tilted fault block and the dip direction for the southern Gulf of Suez and the Nubia structure depth map (Fig. 4) referred to the effect of structure on the oil potentiality in the area.

The Nubia A rock unit rests conformably on PreCambrian (Basement rocks) and is overlained in most places by marine strata of Cenomanian (Raha Formation) (Fig. 5) ${ }^{[8,10-14]}$. Many authors described the Nubia A rock unit as a continental origin (Fluvial-Deltaic) and consists mainly of sandstone with interbedded streak of shale.

\section{Materials and Methods}

Knowledge of the subsurface comes primarily from drilling which is a very expensive process. Geophysical Well logging offers an opportunity to determine the 


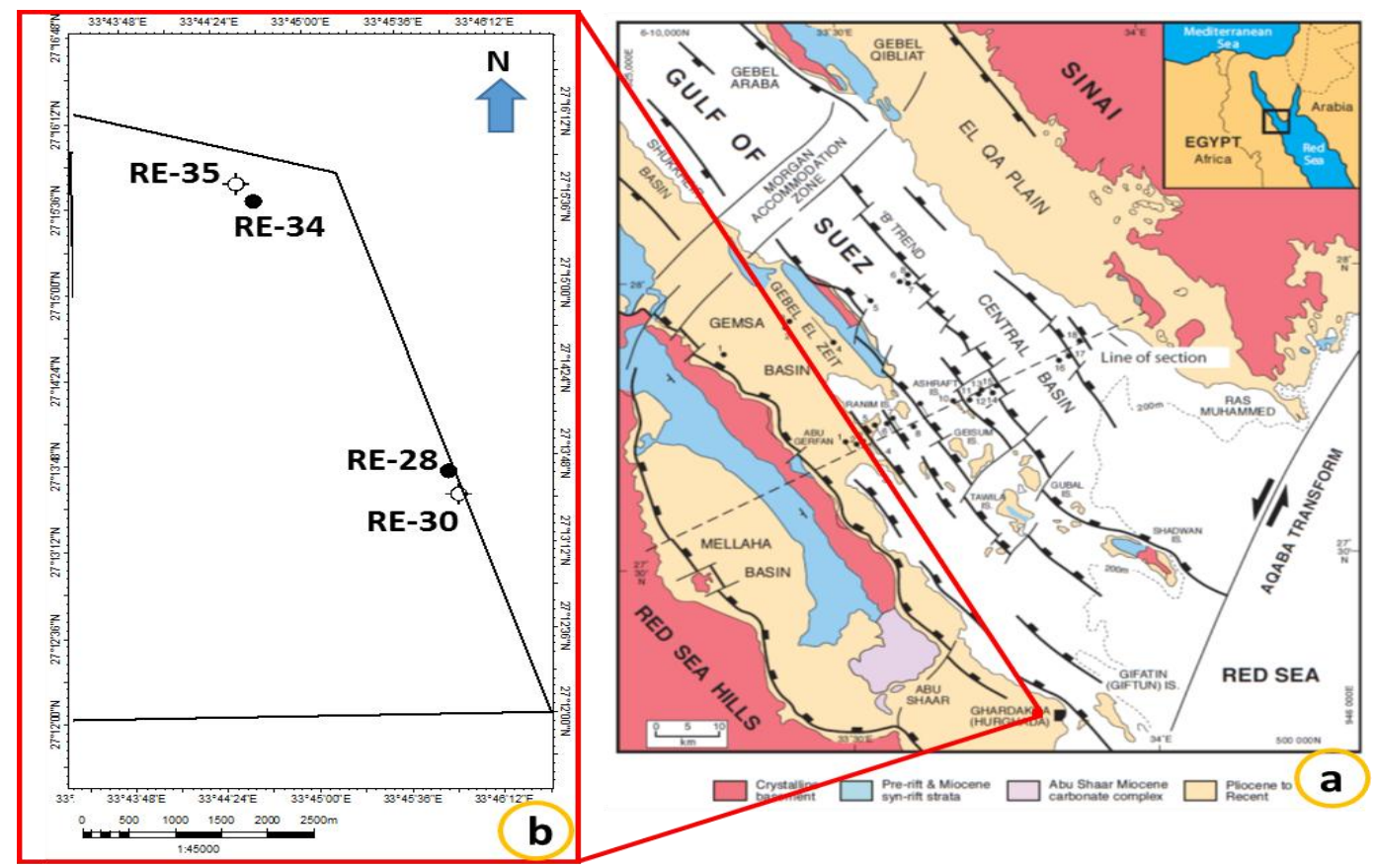

Fig. 1: a- Summary map of the Southern Gulf of Suez (after Bosworth, 1994); b- Study area with studied well locations.

composition, variability and physical properties of the rocks around the well thereby enabling a proper understanding of the subsurface at a cheaper cost ${ }^{[15]}$. The aim of this study is to include the evaluation of
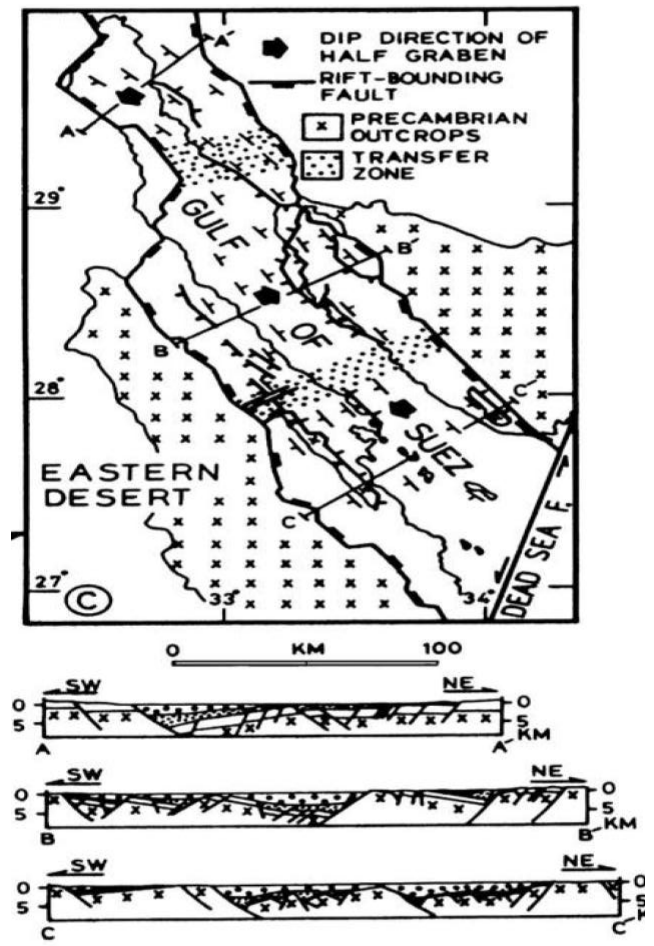

Fig. 2: Simplified structural map of the Suez rift and structural cross sections through the three half Grabens ${ }^{[9]}$. petrophysical reservoir properties for the estimation of hydrocarbons in porous zones encountered in the Lower Cretaceous (Nubia A rock unit), which are penetrated by more than 50 wells in the West Esh El Mallaha Oilfield.

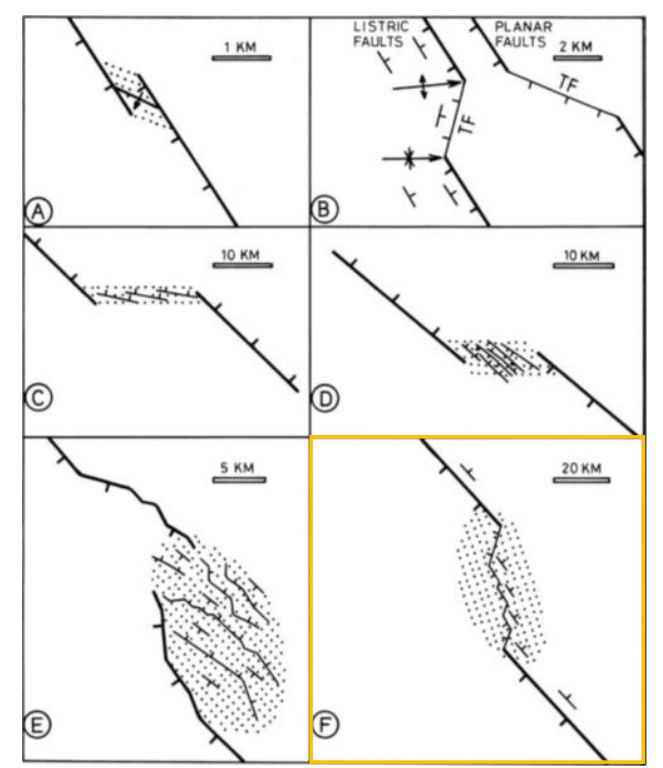

Fig. 3: Different types of fault-to-fault Transfer Zones. (A) Relay Ramp; (B) Linking Transfer fault (TF); (C) En Echelon step faulting; (D) En Echelon horst-graben faulting; (E) Tilted fault blocks; $\underline{(\mathbf{F})}$ $\underline{\text { Zigzag fault array }}^{[9]}$. 


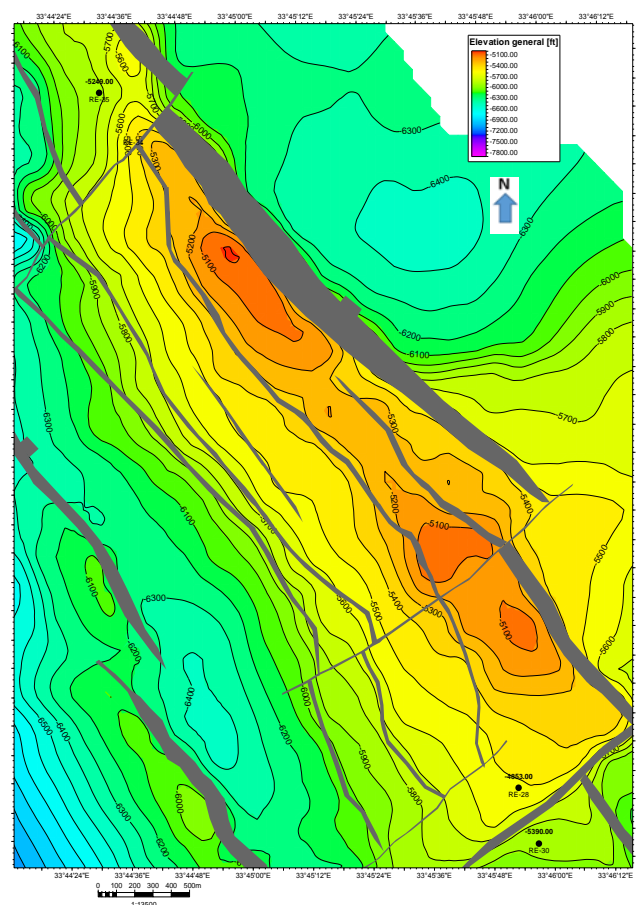

Fig. 4: Nubia Structure Depth Map form West Esh El Mallaha Field.

\section{Available Data}

Four vertical wells were selected to the study, RE-28, RE-30, RE-34, and RE-35. Wells RE-34, RE-35 are located to the north north west of RE-28, RE-30 that cover part of West Esh El Mallaha study area (Fig. 1). They selected based on the different log types. These logs include gamma ray (GR), caliper (CAL), bit size (BS), shallow (Rxo) and deep (RLA 1-5) resistivities, formation density compensated (RHOB), borehole compensated sonic (DT), compensated neutron porosity (NPHI) and photoelectric formation (PEF). These logs are checked and matched for depth before processing and interpretation.

\section{Log Analysis Methodology}

Throughout the four wells, the data should be corrected to different environmental effects. Different calculation processes of reservoir parameters, such as volume of shale, porosity, lithological identification and fluid saturation of the studied intervals are curried out first.

The available sets of logs are correlated and depth matched with each other. The well-log analysis was performed, using Techlog software. This program allows making good and reliable interpretation of raw data. The digitized data, particularly resistivity, gamma ray, neutron and density, are corrected for most of the different extraneous factors influencing them during drilling and recording operations such as borehole size, mud weight, mud cake thickness, mud salinity, formation water salinity and formation temperature.

Corrected well-logs and estimated reservoir parameters, are plotted versus depth, including vertical and lithological identification cross-plots. Cross-plots were used to show the lithological and mineralogical compo-

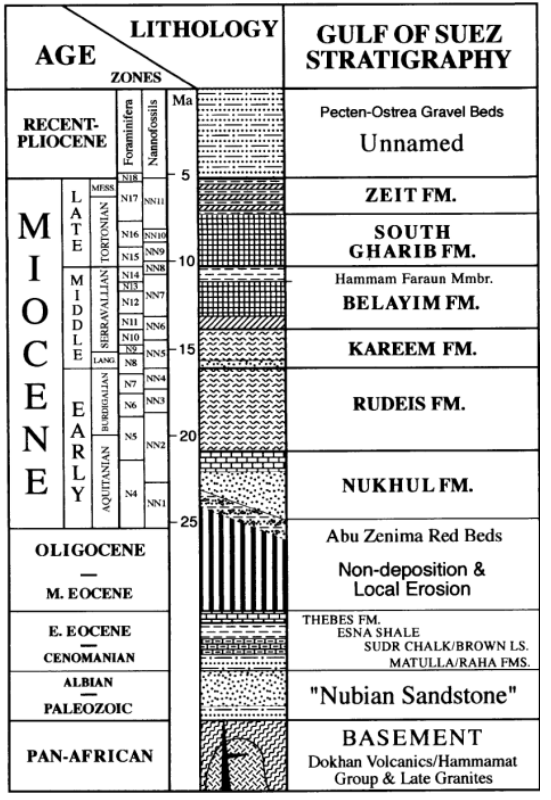

Fig. 5: Generalized stratigraphy and micro fossil zonations of the Southern Gulf of Suez. (Modified by $\left.{ }^{[5]}\right)$.

nent of the Nubia A rock unit. These crossplots give a quick look about the rock and mineral contents in a qualitative way. Some of these cross-plots give the amount of lithologic contents in a quantitative way. Such cross-plots are RHOB vs PEF and $\mathrm{M}$ vs $\mathrm{N}$ and Umatrix vs RHOmaa plots and PHIN vs PHID to identify the type of shale content.

The analysis was made in the following flow: Determination of the shale volume in the formations, using two methods: single curve clay indicator (linear GR method) and Double-curveclay indicator (Neutron Density crossplot). The volume of shale chosen for the zones was the arithmetic average of these two methods " $V_{\text {sh }}$ final". Total and effective porosities calculation using Neutron-Density and Schlumberger charts "computed internally by software". Determination of the water saturations $\left(S_{\mathrm{w}}\right.$ and $S_{\mathrm{xo}}$ ) using Archie Equation. Determination of hydrocarbon saturation in the analyzed rock units.

\section{Results and Discussion}

\section{I) Lithology and Mineralogy Components}

The identification of the matrix components is well defined through different cross-plots where different types of matrix appear by combining different well logs. These cross-plots of the Nubia A rock unit in the West Esh El Mallaha Oilfield can be illustrated as follows:

\section{a) RHOB-PEF Cross-plot Identification}

The bulk density versus photoelectric cross-plot can be used to identify the minerals. The cluster of points on this plot (Fig. 6) shows majority is sandstone with some points reflect to dolomite, this may be affected by presence of shale and clay with some points reflect to limestone on upper part in wells (RE-35,34). 


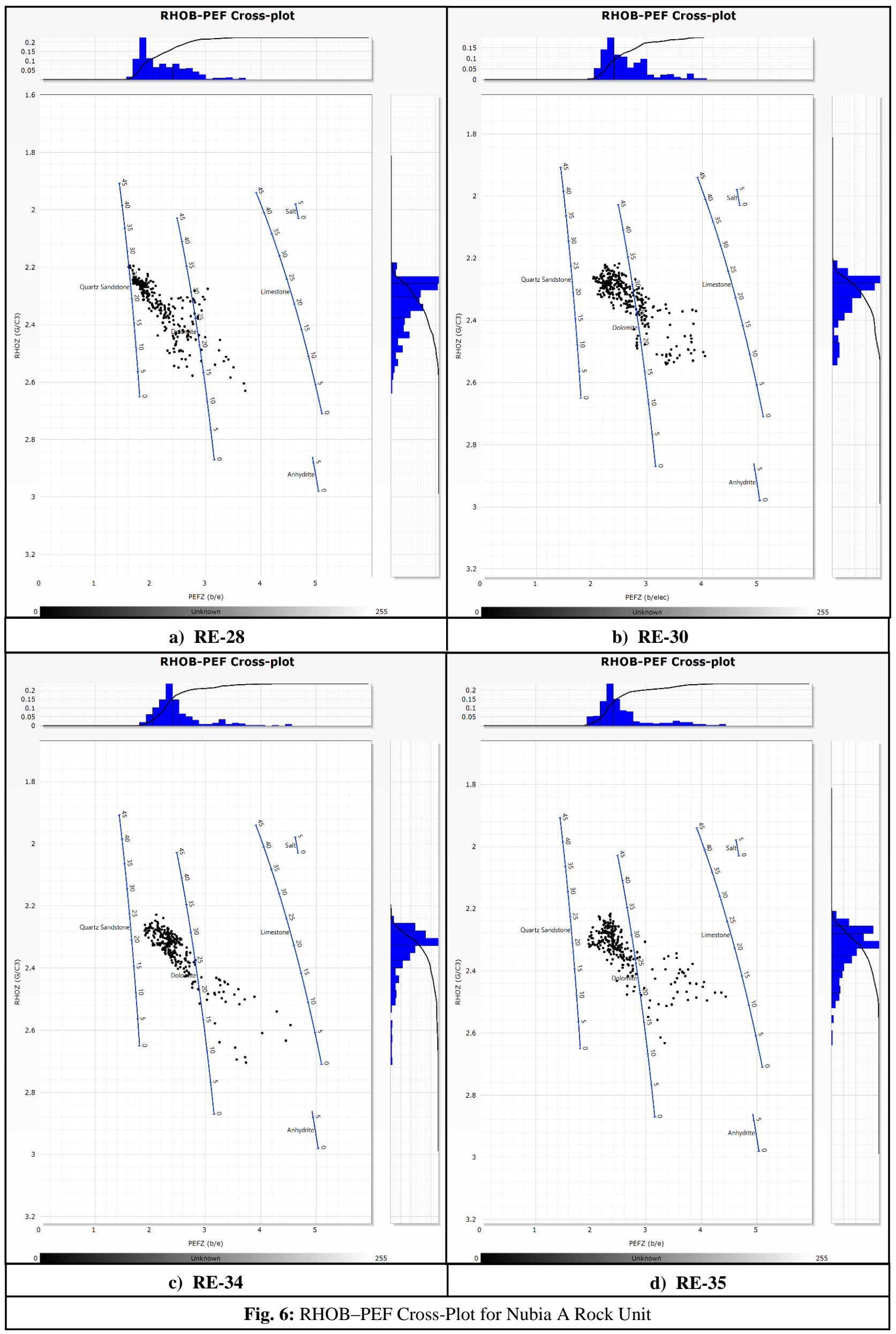




\section{b) M-N Plot Identification}

The M-N cross-plots (Fig. 7) reveal the predominance of sandstone minerals (quartz), where the corresponding points are shifted towards the shale area. And some points referred to Limestone (calcite) in wells (RE35.34) in general.

\section{c) Umatrix - RHOmaa Plot Identification}

The Apparent matrix grain density - Apparent matrix volumetric cross section plots (Fig. 8) strongly reflect the minerals accumulated point around the sandstone minerals (quartz), which the corresponding points are shifted toward the kaolinite minerals, the shifted point toward the dolomite point reflected the influence of shale. Few points show move toward the calcite referred to found minor streak of limestone on the two wells (RE$34,35)$.

Finally, it can be concluded that the lithology of this reservoir from those cross-plots is sandstone, shale and siltstone intercalations and one minor streak of limestone in the upper part of the unit in wells (RE-34, 35). The sandstone content is generally high as shown from the highest plotted points along the sandstone lines in those cross-plots.

\section{II) Shale Types and Types of Porosity}

The shale type can be defined by determining these points, the clean point $(\mathrm{Sd})$, the shale point $(\mathrm{Sh})$ and the quartz point $(\mathrm{Q})$, in which $\mathrm{PHID}=\mathrm{PHIN}=0$. The laminated shale points will fall on the Sd-Sh line, the dispersed shale will deviate the points to the left of this line and structural shale will deviate the points to the right of the line (Schlumberger Application, $1974^{[16,17]}$ ). The plotted data for the Nubia A rock unit in the four wells in the study area mainly dispersed with few points reveals the laminated shale and few points migrated into the effect of organic matter zone (Fig. 9).

\section{III) Hydrocarbon Potential}

The hydrocarbon potentiality necessities obtaining accurate rock properties and hydrocarbon accumulation and integrating this information with subsurface setting in the study area ${ }^{[18]}$. The analysis includes vertical petrophysical distribution cross-plots of the analyzed data in each well and the horizontal iso-parametric configuration maps ${ }^{[18-21]}$.

\section{Vertical Distance of Hydrocarbon Occurrences}

The study of the Nubia A rock unit from four studied wells of West Esh El Mallaha oil field using different type of $\log$ analysis and the methods used to give a better and more reliable estimate of petrophysical properties, resulted in several points which could enhance our understanding and evaluation of the reservoir characters of Nubia A Formation. These points include:

The distinction between gross and net pay is made by applying cut-off values in the petrophysical analysis. In this study, cut-off values of effective porosity $(\geq 0.15)$, volume of shale $(\leq 0.40)$ and water saturation $(\leq 0.45)$ were used to identify pay intervals. Using the cut-off limits, flag curves were created in the database for net reservoir interval and gross reservoir. The net to gross ratio determined could be used to calculate the volume of gas originally in place. However, the calculation of volume of hydrocarbon is not part of the scope of this study.

Presented in (Table 1) below are the calculated net pay summary for wells with the corresponding graphics in (Figs. 10 - 13).

In well RE-28, The Nubia A rock unit showed net pay potentials as presented in Fig. 10, The net pay $(56.5 \mathrm{ft}$ ) and average porosity from $21.1 \%$, water saturation 18.2 $\%$ and volume of clay $17.8 \%$.

In well RE-30, The parameters calculated for the Nubia A rock unit is also showing that this is a dry well because not recorded the cut off values and shown in (Fig. 11).

The Nubia A rock unit in well RE-34 calculated net pay thickness is $82 \mathrm{ft}$, average porosity is $19.2 \%$, water saturation is $21.5 \%$ and volume of clay is $19.7 \%$. These results are presented in Fig. 12.

The calculated data for Nubia A rock unit well RE-35 show that it is a dry rock unit because the parameters didn't reach to the cut off values showed in Fig. 13.

Table 1: Summary of calculated reservoir pay parameters for Nubia A rock unit Well RE-28, 30, 34, 35.

\begin{tabular}{|c|c|c|c|c|c|c|c|c|c|c|c|c|c|c|c|}
\hline \multicolumn{16}{|c|}{ RE-28 } \\
\hline Formation & \multicolumn{2}{|c|}{ Depth (ft) } & Thickness & Gross & Net Pay & $\begin{array}{l}\text { Net to } \\
\text { Gross }\end{array}$ & $\begin{array}{l}\text { Av_VSH } \\
\text { _FINAL }\end{array}$ & Av_PHIE & $A v \_S W$ & $A v \_B V W$ & Av_BVWXO & Av_sh & Av_SXO & Av_shr & Av_shm \\
\hline Nubia Fm & 5638 & 5768 & 130 & 73 & 56.5 & 0.774 & 0.178 & 0.211 & 0.182 & 0.037 & 0.132 & 0.818 & 0.635 & 0.365 & 0.453 \\
\hline \multicolumn{16}{|c|}{ RE-30 } \\
\hline Nubia Fm & 5994 & 6152 & 158 & 94 & - & - & - & - & - & - & - & - & - & - & - \\
\hline \multicolumn{16}{|c|}{ RE-34 } \\
\hline Nubia Fm & 5557.368 & 5683 & 125.632 & 82 & 82 & 1 & \begin{tabular}{|l|}
0.197 \\
\end{tabular} & 0.192 & 0.215 & 0.04 & 0.108 & 0.785 & \begin{tabular}{|l|}
0.575 \\
\end{tabular} & $\mid 0.425$ & 0.36 \\
\hline \multicolumn{16}{|c|}{ RE-35 } \\
\hline Nubia Fm & 5938 & 6064 & 126 & 68 & - & - & - & - & - & - & - & - & - & - & - \\
\hline
\end{tabular}









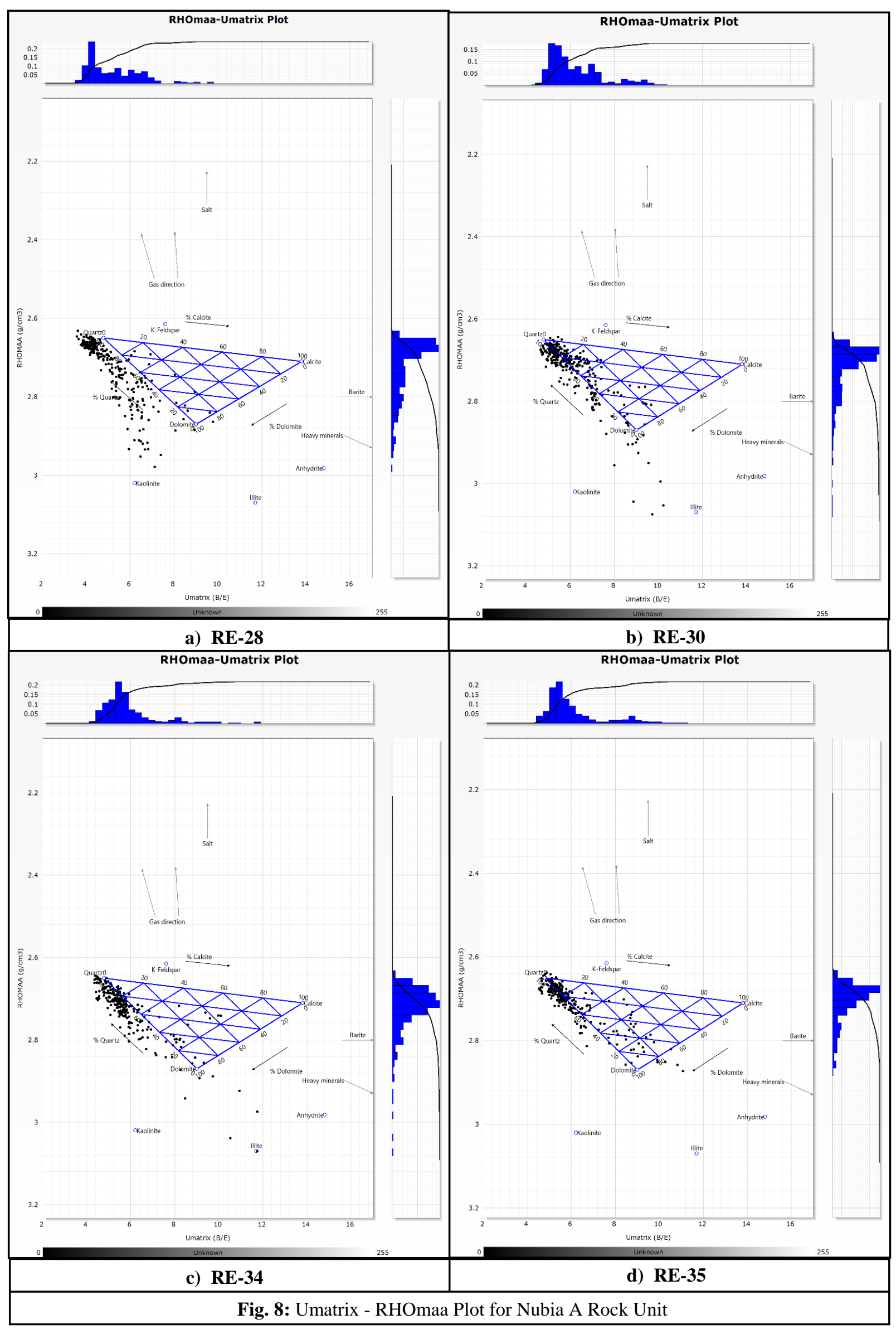




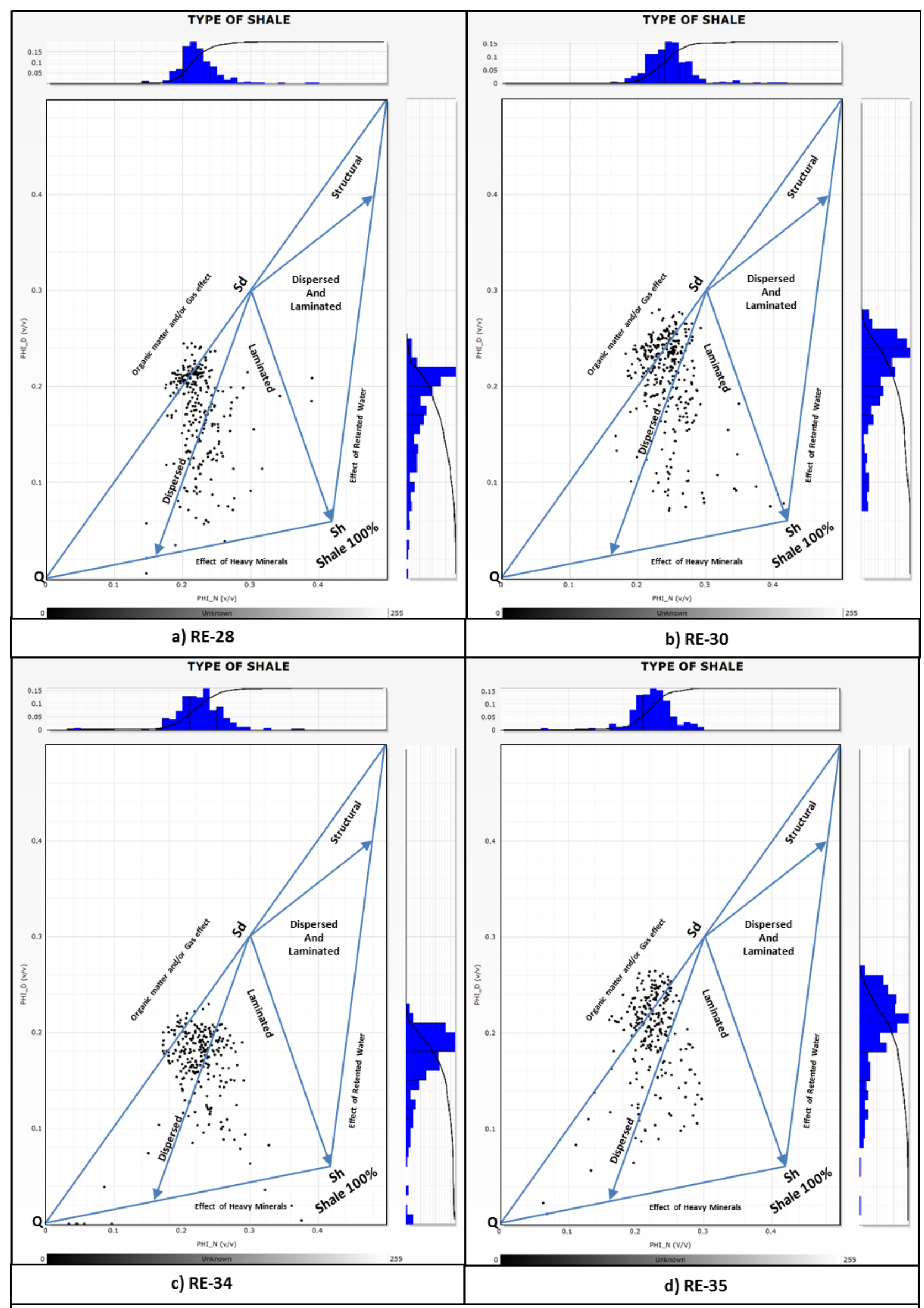

Fig. 9: Dia-porosity Cross-plot for Nubia A rock unit 


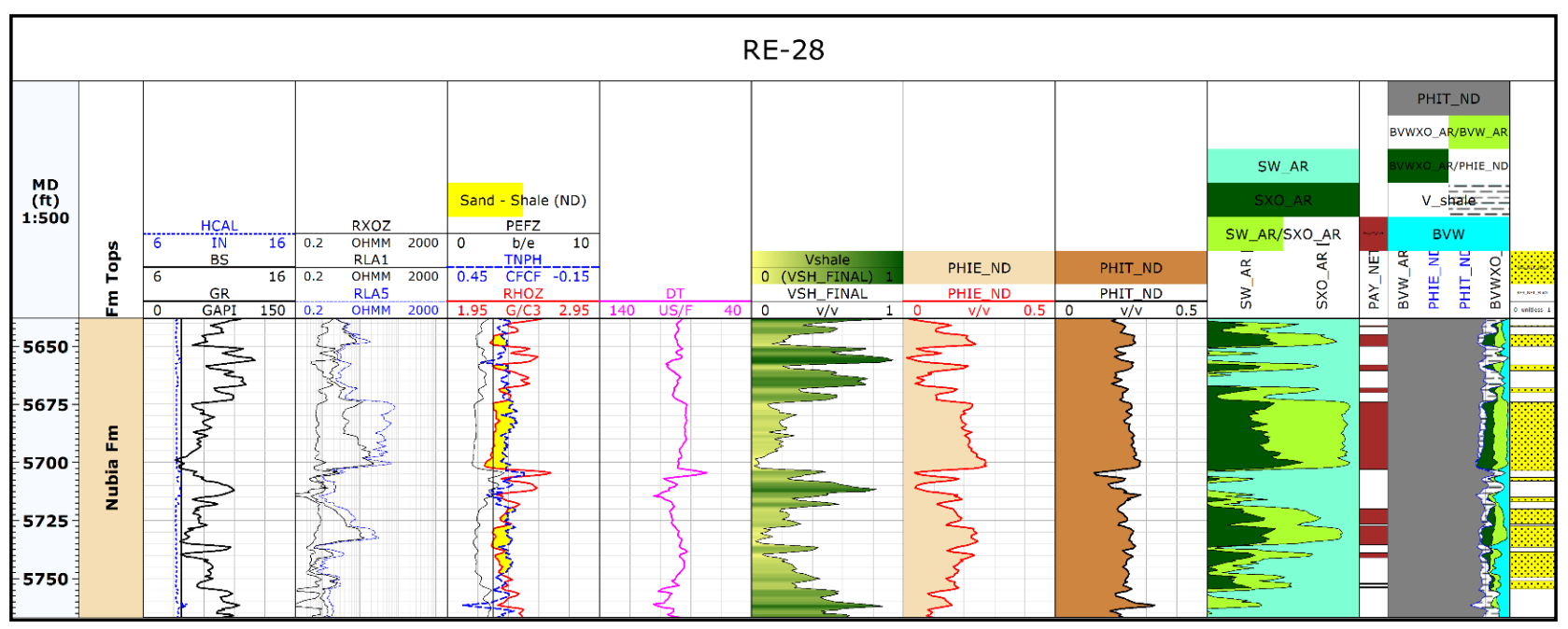

Fig. 10: Well RE-28 Showing Calculated Reservoir Parameters and Pay Flags for Nubia A Rock Unit.

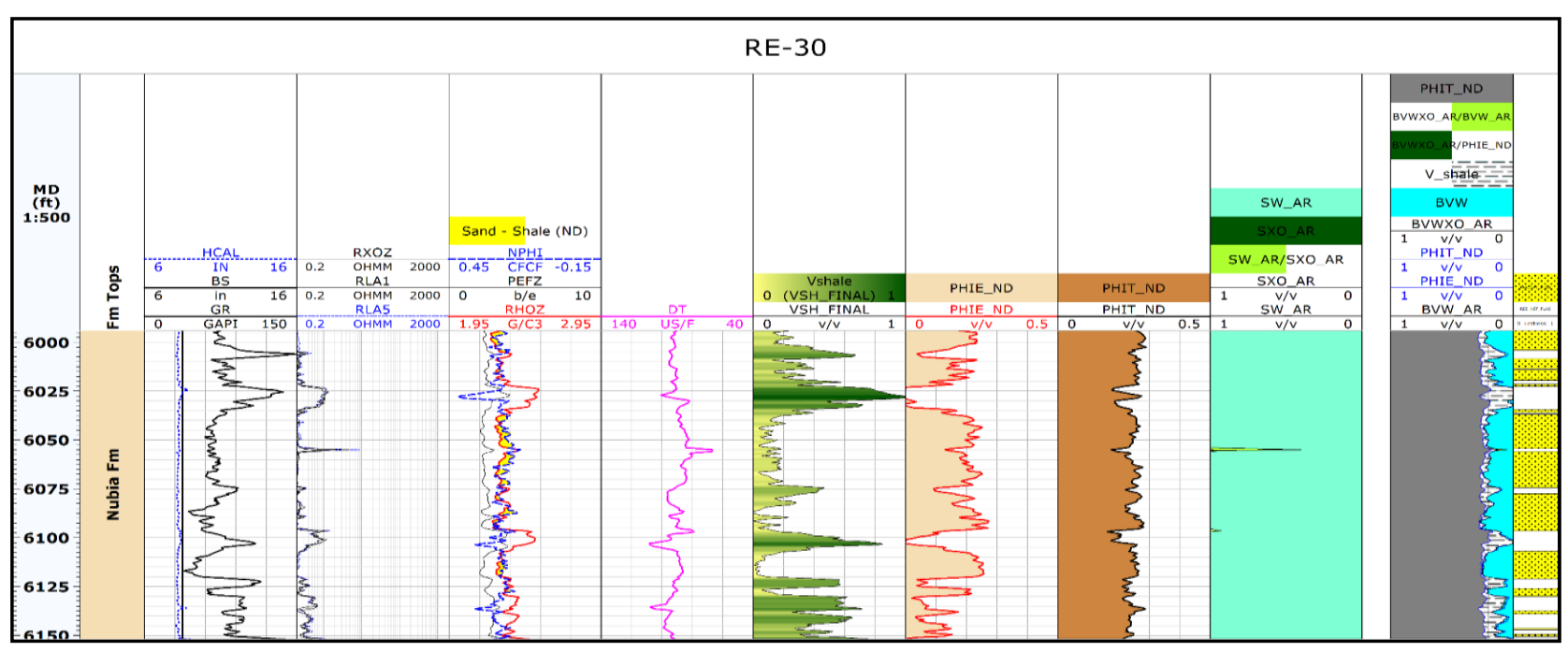

Fig. 11: Well RE-30 Showing Calculated Reservoir Parameters and Pay Flags for Nubia A Rock Unit.



Fig. 12: Well RE-34 Showing Calculated Reservoir Parameters and Pay Flags for Nubia A Rock Unit. 


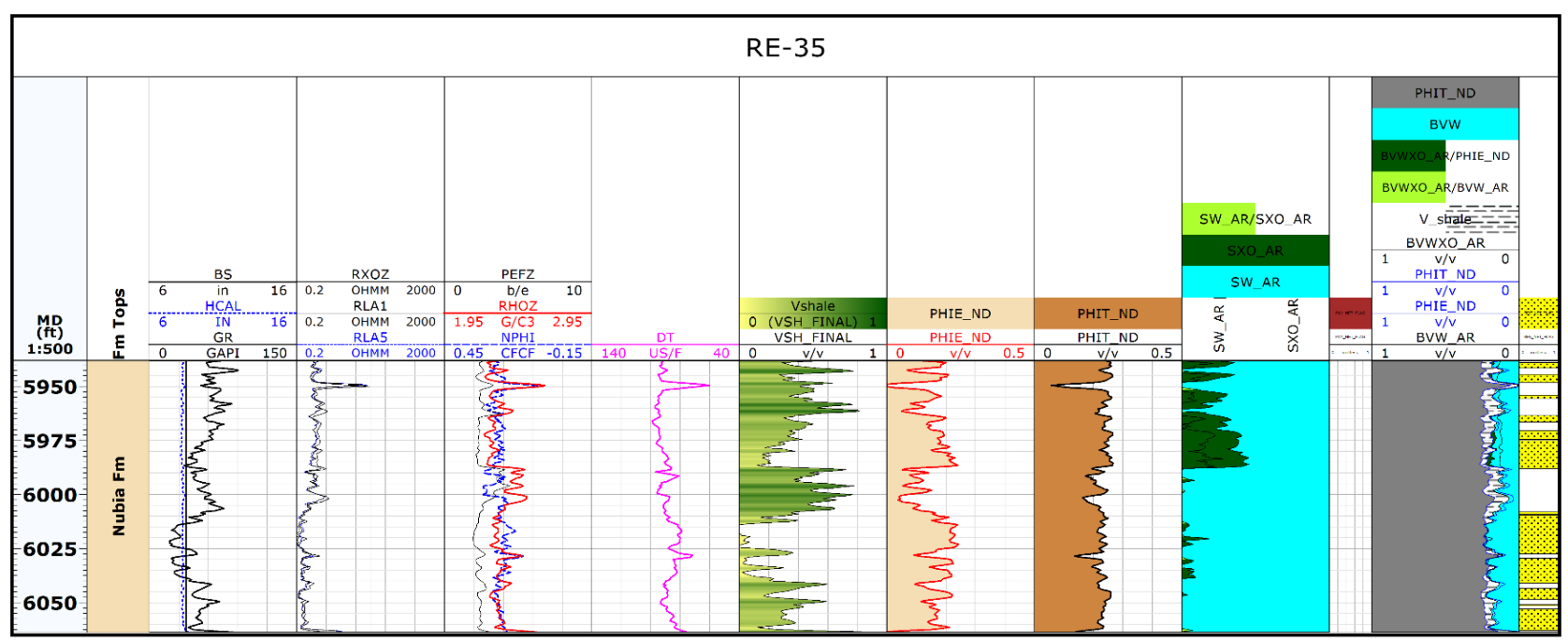

Fig. 13: Well RE-35 Showing Calculated Reservoir Parameters and Pay Flags for Nubia A Rock Unit.

\section{Conclusion}

The different cross-plots of given data are utilized to predict the lithology for the Nubia A rock unit in terms of mineral constituents and matrix identifies through this cross-plots. The interpretation of the cross-plots for Nubia A rock unit refers that the main composition is sandstone with shale interbeds with some clay minerals like kaolinite in part.

The results from PHID-PHIN cross-plot for the Nubia A rock unit in the four wells in the study area revealed the dispersed shale is dominating with few laminated shale and some points reflected the presence of organic matter which affected on data.

On the other hand, the estimated petrophysical parameters from available well logs data (GR, CAL, BS, Rxo, RLA 1-5, RHOB, DT, NPHI, and PEF) helped to know the reservoir characteristics for Nubia A rock unit. The Nubia sandstone is ranging in thickness from 125-158 $\mathrm{ft}$ in the four studied wells, and the two wells RE-28 and RE-34 show good performance reservoir, effective porosity $19-21 \%$, water saturation $15-21 \%$ and pay thickness 56-82 ft. The other wells RE-30 and RE-35 is referred to as dry holes due to the trap location but the Nubia A rock unit in this well is a good reservoir but not counter because it is dry hole and have $100 \%$ water saturation.

Finally, the study revealed many information for Nubia reservoir and refer that the Nubia sandstone has good reservoir characterization, and the oil potentiality back to the position of Nubia within the structure in the area. The Nubia structure map showed the position of the four studied wells and reflect the effect of the structure on the oil potentiality in the study area.

\section{References}

1) Gawthorpe, R. L., Hurst, J. M. and Sladen, C. P. (1990). Evolution of Miocene footwall-derived coarse-grained deltas, Gulf of Suez, Egypt: implications for exploration. Amer. Ass. Petrol. Geol. Bull. 74: 1077-1086.
2) Patton, T. L., Moustafa, A. R., Nelson, R. A. and Abdine, A. S. (1994). Tectonic evolution and structural setting of the Gulf of Suez rift, Egypt. In: Interior Rift basins, (Ed. Landon, s.), AAPG Memoir, 59: 9-55.

3) Sharp, I. R., Gawthorpe, R. L., Underhill, J. R. and Gupta, S. (2000). Fault-propagation folding in extensional settings: Examples of structural style and syn-rift sedimentary response from the Suez Rift, Sinai, Egypt. Geological Society of America Bulletin, 112: 1877-1899.

4) Sharp, I. R., Gawthorpe, R. L., Armstrong, B. and Underhill, J. R. (2000). Propagation history and passive rotation of mesoscale normal faults: implications for syn-rift stratigraphic development. Basin Research, 12: 285-306.

5) Bosworth, W. (1995). A high-strain rift model for the southern Gulf of Suez (Egypt). In: J.J. Lambiase (Ed.), Hydrocarbon Habitat in Rift Basins, Geol. Soc. Lond. Spec. Paper 80: 75-112.

6) McClay, K. R., Nicols, G. J., Khalil, S. M., Darwish, M. and Bosworth, W. (1998). Extensional tectonics and sedimentation, eastern Gulf of Suez, Egypt. In: B.H. Purser and D.W.I. Bosence (Eds.), Sedimentation and Tectonics of Rift Basins: Red Sea-Gulf of Aden, Chapman and Hall, London, pp. 223-238.

7) Bosworth, W. and McClay, K. (2001). Structural and stratigraphic evolution of the Gulf of Suez rift, Egypt: A synthesis. In: Ziegler, P.A., Cavazza, W., Robertson, A.H.F., Crasquin-Soleau, S., (Eds.), PeriTethys Memoir 6: Peri-Tethyan Rift/Wrench Basins and Passive Margins, Mémoires du Muse'um National d!Histoire Naturelle de Paris 186, 567-606.

8) Schutz, K. I. (1994). Structure and stratigraphy of the Gulf of Suez, Egypt. In: Interior Rift Basin, (ed. S.M. Landon), AAPG Memoir 59, Tulsa, Oklahoma USA, p. 57-199. 
9) Moustafa, A. R. (2002). Controls on the geometry of transfer zones in the Suez rift and northwest Red Sea: Implications for the structural geometry of rift systems. Amer. Ass. Petrol. Geol. Bull. 86: 9791002.

10) Klitzsch, E., Roesch, M. and Herrmann-Degen, W. (1990). Wadi Qena: Paleozoic and precampanian cretaceous strata, In: R. Said (ed.), The geology of Egypt, $2^{\text {th }}$ edition, A. A. Balkema / Rotterdam / Brookfield, p. 321-327.

11) Abdallah, A. M., Darwish, M., El-Arwf, M. and Helba, A. A. (1992). Lithostratigraphy of the precenomanian clastics of north wadi Qena, eastern desert. In Geology of the Arab World, Cairo university, p. 255-282.

12) Khalil, M., El Nagdy, E., Rahman, H. A. and Comisso, M. (1998). Frontier exploration in the southern Egyptian Red Sea: superimposed Cretaceous and Tertiary rift tectonic in newly discovered, untested Ras Banas. Sub-Basin. 14 ${ }^{\text {th }}$ Petroluem Exploration Seminar, Egyptian General Petroleum Corporation, Cairo, p. 1-15.

13) El Sheikh, M., Aly, H. and Imperatore, R. (1998). Ashrafi field - Gulf of Suez: A case history of exploration and development in a complex Geological setting. $14^{\text {th }}$ Petroluem Exploration Seminar, Egyptian General Petroleum Corporation, Cairo, p. 322-337.

14) Swidan, N. and Khairy, A. (1998). Geological evolution of zeit bay field, Gulf of Suez, Egypt. $14^{\text {th }}$
Petroluem Exploration Seminar, Egyptian General Petroleum Corporation, Cairo, p. 310-321.

15) Ofwona, C. (2010). Introduction to Geophysical Well Logging and Flow Testing, Exploration for Geothermal Resources, UNU-GTP, GDC and KenGen.

16) Aly S. A. (1989). Evaluation of petrophysical properties of reservoir rocks using well logging analysis in Abu Gharadig Basin, Western Desert, Egypt. Ph.D. thesis, faculty of science, Ain Shams University, $346 \mathrm{p}$.

17) Brook, J. (1984). Analyzing your logs, Vol. II. Advanced open hole log interpretation. Petro-Media, Inc., Tyler.

18) Aly, S. A., Hassan, N. M. and El-Sayed, A. S. (2000). Petrophysical characteristics and oil potentialities of the Rudeis and Kareem Formations in Belayim marine oil field. In $5^{\text {th }}$ international conference on the geology of Arab World, Cairo university. P. 791-808.

19) Asquith, G. B. and Gibson, C. R. (1997). Basic well $\log$ analysis for geologists. American Association of Petroleum Geologists, Tulsa, $215 \mathrm{p}$.

20) Rider, M. (2000). The geological interpretation of well logs. Rider French Consulting Ltd., Southerland, $280 \mathrm{p}$.

21) Asquith, G. and Krygowski, D. (2004). Basic well $\log$ analysis. American Association of Petroleum Geologists, Tulsa, 244 p. 